\title{
LANGUAGE, SILENCE AND TRANSLATION IN EMANUELE CRIALESE'S POLYGLOT MIGRATION FILM NUOVOMONDO - GOLDEN DOOR (2006) ${ }^{1}$
}

\author{
Lorena Carbonara* \\ Università di Bari
}

\begin{abstract}
This essay aims to examine various aspects of Emanuele Crialese's Nuovomondo - Golden Door (Italy-France, 2006), with particular attention given to the use of multiple languages (English, Italian and Sicilian dialect) in this migration film, and to their subtitle translation for the DVD version of the film. The language interplay in Nuovomondo raises a series of questions concerning the possibility - and impossibility - of translating culturally bound material from a polyglot multi-semiotic product into another language/culture. Assuming the transnational importance of this film as an epitome of cultural (un)translatability, this essay will scrutinize and enlarge on a series of questions relating to the role of language, silence and translation. The film represents a perfect example of how language played a crucial role in defining power relationships between migrants and Americans at the "(un)welcoming" harbor in the twentieth century. It also raises questions on how forms of inclusion, subversion and legitimation were articulated in a dominant culture - such as that of the US - in response to otherness, and on the role of translation also as an exercise of power and identity (re)negotiation.
\end{abstract}

Keywords: Polyglot Film. Migration. Language. Dialect. Subtitling.

\footnotetext{
${ }^{1}$ Research project co-financed by Fondo di Sviluppo e Coesione 2007-2013 - APQ Ricerca Regione Puglia "Programma regionale a sostegno della specializzazione intelligente e della sostenibilità sociale ed ambientale - FutureInResearch".

* Lorena Carbonara: Doctor of Philosophy in Translation Studies: Theory and Practice (2009) from the University of Bari, Italy. Master in Cultural Studies, Communication and Visual Culture, (2006) and BA in Foreign Languages and Literature (English and Portuguese) (2004), both from the University of Bari, Italy. She is a research assistant in Language and Translation at the University of Bari (Future in Research, Regione Puglia), Italy. Bari, Apulia, Italy. E-mail: lorena.carbonara@uniba.it
} 


\title{
LÍNGUA, SILÊNCIO E TRADUÇÃO NO FILME POLIGLOTA SOBRE MIGRAÇÃO DE EMANUELE CRIALESE, NUOVOMONDO - GOLDEN DOOR (2006)
}

\begin{abstract}
Resumo: O presente artigo centra-se na análise do filme Nuovomondo - Golden Door (Itália-França, 2006), de Emanuele Crialese, dando particular atenção ao uso de diferentes idiomas (inglês, italiano e dialeto siciliano) neste filme sobre migração e à respetiva tradução para legendagem do filme em DVD. As interações linguísticas que têm lugar em Nuovomondo colocam uma série de questões relativamente à possibilidade - e impossibilidade - de traduzir material culturalmente específico de um produto multi-semiótico para uma outra língua/cultura. Ao assumir a importância transnacional do filme como epítome de (in)traduzibilidade cultural, este ensaio examinará e discutirá questões relacionadas com o papel da língua, do silêncio e da tradução. O filme constitui um exemplo perfeito de como a língua desempenhou um papel central na definição das relações de poder entre migrantes e norte-americanos no porto "(in) desejável" novecentista. Também discute de que modo formas de inclusão, subversão e legitimação são articuladas numa cultura dominante, como a dos Estados Unidos, em resposta à alteridade e o papel da tradução como exercício de poder e de (re)negociação identitária.
\end{abstract}

Palavras-chave: Filme Poliglota. Migração. Língua. Dialeto. Legendagem.

\section{Premise}

Between the second half of the nineteenth century and the early twentieth, 11.1 million Italians migrated en masse to the US, contributing greatly to the expansion of American population, which saw a $28 \%$ increase from 1870 to 1913 (Moretti 1999, 640). Migrants were mostly illiterate and, coming from the rural areas of the South, not particularly accustomed to living and working in urban areas. They usually settled in suburbs around the harbor in New York where other Italian families had already established communities, and would send home propaganda postcards showing the abundance of the American lands: enormous fruits and vegetables, coins hanging from trees, gigantic hens, etc. This 
representation of America as the New World, the land of abundance and opportunity, reached the Old World through these pictures that channeled the desire of many Italians in search of a better life.

With the Immigration Act of 1917, along with the usual mental and physical tests, the US government started to require a literacy test in English in order to reside in the country, thus building a linguistic boundary that reinforced the preexisting cultural one (Roediger 2005). The Act included: the increase of the head tax; the expansion of the categories of "undesirable aliens"; the exclusion of South-Asian immigrants and the containment of new enforcement provisions. ${ }^{2}$ Language competence and literacy were an additional factor of discrimination against migrants from rural areas, such as Italians who largely spoke their regional dialects, only partially fluent in their own national language.

Among the numerous films narrating this story of migration, Emanuele Crialese's Nuovomondo (Italy-France 2006) - translated into English as Golden Door - is one of the most interesting examples. It may be considered a polyglot film, according to the definition given by Ortega: "a type of cinematic production in which languages play their social function and bring to light characters' cultural and social differences" $(2011,19)$. It manages to represent the transcontinental journey of Italian migrants and their encounter with the possibility and/or impossibility of "translation" into the US system, focusing on their perspective of the New World.

The link between translation and migration has been widely discussed by scholars of translation studies as well as sociologists, anthropologists and literary theorists. According to Polezzi:

The terrain on which translation encounters migration is thus represented either as a utopian or a dystopian location but always as one where crucial stakes are placed and played out over "our" future. Those stakes concern shared understandings and operative formulations of notions of

\footnotetext{
${ }^{2}$ See http://immigrationtounitedstates.org/588-immigration-act-of-1917.html.
} 
identity, community and home, as well as of the way these relate to institutions and apparatuses: the nation state (with its corollaries of national languages, cultures, literatures and so on), citizenship and the rights attached to it, the policing of geographical and social borders. $(2012,346)$

This essay aims to examine Nuovomondo with particular attention to the film's languages and to their rendition for the subtitled version of the film on DVD. ${ }^{3}$ The languages used in the film are: English, the US master language into which the migrants are translated as soon as they arrive at Ellis Island; Italian, the national language the protagonists are supposed to be able to speak; and Sicilian dialect, their actual mother tongue. The analysis of the film raises questions concerning the possibility, and impossibility, of translating the film's culturally bound material into another language and thus for a non-Italian audience. It is indeed interesting to ponder some of the choices made by the translator for the English-subtitled version and the translation policies at the basis of the film's promotion and distribution in the US. As Cronin affirms in Translation Goes to the Movies:

Though film scholars might be reluctant to dwell on language for fear of relegating image to a secondary position, or only consider translation in the context of "technical" concerns of dubbing and subtitling, the issue raised by the representations of translation are too important and persistent to be ignored in any attempt to understand the impact of cinema as one of the pre-eminent idioms of the modern age. $(2009$, xii)

In this case study, translation is considered both as a linguistic practice and as a metaphor condensing the encounter - and clash

${ }^{3}$ Crialese E. Nuovomondo - Golden Door, DVD, Miramax, 2008. 
- between worlds: America and the world of migrants, Italian and foreign audiences and film distributors. An overview of the different ways the film was presented to Italian and foreign markets through posters and trailers is also provided in order to stress how the narrative of migration can be constructed and re-mediated through acts of constant translation.

Furthermore, since Crialese "deploys stylistic choices capable of translating the narration (in literary terms) of the migration from Sicily to New York into photography" (Zaccaria 2009, 190; my translation), ${ }^{4}$ the inter-medial featuring of real historical postcards in the film also deserves a mention. As Pethö observes, "the imprints of certain intertexts have the power of becoming authentic traces of the reality of a certain age" $(2011,13)$, and this is true in this film since America "enters" the characters' lives through its visual postcard depiction. Viewers and the characters alike are taken to "another world"; thus the journey effectively starts before the actual departure.

The interplay of languages and also silence, as embodied by one of the characters, and the possibility/impossibility of translation represent the focus of the following analysis. Among the Babel of languages spoken on the transatlantic and at Ellis Island, Sicilian dialect is the auditory fil rouge of the film. Indeed, the protagonists are often unable to understand Italian and always need an interpreter from/into the English language; polyglot interpreters firstly translate from dialect into English for the US officials and then back into Italian, proving their competence in three languages. In such a transnational and transcultural context, migrants themselves are seen as agents of translation (Cronin 2006).

The essay is divided into five sections that analyze: the film plot; the symbolic clash between the two worlds embodied by the characters; the actual role of language and silence over the course of this inter-cultural encounter that requires translation; the

${ }^{4}$ Original: "Crialese opera delle scelte stilistiche in grado di tradurre la narrazione (il letterario) della migrazione dalla Sicilia a New York in fotografia” (Zaccaria, 2009, 190). 
problematics raised by translation for the English-subtitled version of the film; and the politics of promotion and distribution of the film in Italy, France and the US, highlighting also the influence of paratextual elements (mainly posters, trailers and title) in the reception of the migration narrative in different contexts.

\section{Film plot}

At the beginning of the 1900s, Salvatore Mancuso leaves Sicily for the United States of America with his two sons, his elderly mother Fortunata, and two young women betrothed to Italo-American men. On their way to the New World, they meet an English lady, Lucy, who is traveling alone on the same ship. Salvatore falls in love with the strange lady. On their arrival at Ellis Island, all the passengers follow the procedures for legal entry into the US. Salvatore and Lucy get married on Ellis Island, as do many other Italo-American men and Italian women on disembarking from their jouneys of hope. Fortunata and Salvatore's mute son are both rejected after refusing to take the tests for legal acceptance in the United States.

Once on dry land, the protagonists get lost in the mass of people disembarking, and feel lost in translation when they receive their first orders in English, the language of their supposed "welcome"; lost in all the series of tests they have to undertake; lost in a noman's land such as Ellis Island, where they are not at sea anymore and yet not on the mainland. They inhabit an in-between space, the migrants" "third space," as postcolonial scholar Bhabha (1994) would call it, where their identity is negotiated (in English), their past cancelled, in a certain sense, in order to usher in a future of new beginnings. This is symbolized by the image of the protagonists swimming in a sea of milk at the end of the film.

The abundance of American products, shown in the postcard pictures (which are actually propaganda photomontages that Fortunata calls "paper words"), which had made Salvatore decide to leave for good, are symbols of the promise of wellbeing that America represents. 
But such manipulated images also pre-empt America's fallacy. As a consequence of the imaginative visions that they instigate, Salvatore has hallucinations and dreams of gigantic vegetables while everything around him is dry; he imagines to receive a waterfall of coins to bless his determination to leave Sicily, among other imaginary visions. Imagination replaces reality and another world materializes before his eyes, until Ellis Island is eventually reached after a long transatlantic journey. Once there, thick fog covers the landscape: America is there at last, but it remains invisible.

\section{Old and New Worlds}

Nuovomondo is at the same time a historical document and an allegory. It lets us examine the role translation plays when two worlds come into contact. This encounter includes the languages, cultural habits and ideological constructs at the basis of the two socio-cultural and political systems. The officers at Ellis Island officially represent the so-called American "modern vision", articulated in English, whereas Fortunata embodies an attachment to her Sicilian roots expressed through her proud use of her mother tongue. Her attachment is anything but stubborn, as she can be seen as the only character in the film that questions the rightness of the American model.

In representing "folk from the Old World" at Ellis Island, she questions the legitimacy of the tests migrants are required to take, tests which dictate admission or rejection on the basis of intelligence. Since intelligence is considered hereditary by the American system, as officers clearly explain in the film, these tests are an attempt at keeping the level of American intelligence "high". Even Lucy, the epitome of "the new" in the film and the one who has a mastery of the English language, is touched by this "modern vision", as she defines it satirically.

The attachment to her roots that Fortunata shows throughout the film eventually leads to her rejection from the US. In a certain 
sense, she refuses translation. Her refusal of otherness is also symbolized by her relationship with Lucy. The old woman thinks of her as "troppo straniera" ("too foreign") to marry her son, a widower. In fact, the mystery surrounding the lady is underpinned by various aspects of her "strangeness": she travels on her own, unlike all the other women, she dresses elegantly, she has manners and she has a more equal relationship with the officers at Ellis Island as she speaks the master language, English.

One of the most powerful scenes of the film symbolizing the idea of a split between two worlds is the scene in which the Mancuso family arrive at the port and manage to board the transatlantic, in the midst of a crowd, and the ship slowly sets sail. The crowd, framed from above, appears as a shapeless grey mass that is literally split into two: one part standing on the quayside, and the other on the deck. The detachment, which resembles a tectonic shift, sounds like a slow and painful goodbye, as the people on the two sides of the shot are separated for good. The ones on the ship will undergo the process of translation and assimilation into a new culture and they will never be the same again.

The world recreated on the ship is something of a third world, a third space, a surrogate of the one left behind and, at the same time, the promise of a new, multicultural one. Interestingly, when Salvatore and his son Angelo take their place in the third class and introduce themselves to the other passengers, Salvatore states: "E cu c'avia durmito mai cu tutti sti stranieri tutti insimolo?" ("I have never slept with so many foreigners before"), "Ma che sorta de lingua parlate?" ("Whatever language are you speaking?"), which has a comic ring to it as they are all southern Italians.

\section{Language and Silence}

Language plays a central role in the definition of the characters in Nuovomondo since the protagonists are literally translating themselves into another world. Yet describing the language/silence 
interplay in Nuovomondo, in "Subtitling dialect and cultural-bound language", De Meo affirms:

The film celebrates the power of the image over the word, since sometimes communication takes place through the freezing up of scenes as for example when the lady representing the old world, Salvatore's mother Fortunata, and the one representing the new world, Lucy, look in each other's eyes and, without uttering a word, they pass on a message of solidarity and reciprocal support. Words often overcome their linguistic and denotative function and acquire socio-cultural and connotative meaning. $(2010,24)$

Both words and the lack of them are indeed extremely important and powerful in the film. Fortunata, for example, insolently tells the officers at Ellis Island that they are not God to decide who is fit enough to enter the New World ("la vostra terra dell'altro mondo", literally "your land of the other world," as she defines it). This linguistic act of self-assertion and self-determination is both political and poetic at the same time. Fortunata, speaking dialect to the officers, refuses to be translated into the system.

As Berger and Komori affirm, "migration certainly offers an ideal setting for portraying bi- and pluri-lingual dialogues as well as culture contact and conflict on screen" $(2010,8)$. In polyglot cinema, language becomes a political instrument, the protagonist of an emotional and socio-cultural revolution that brings the spoken word to the fore. Indeed, as the authors contend: "while literature uses language in its written form, cinema and theater have the advantage of allowing their audience to experience language at an acoustic level" (8). Also the audience may therefore experience linguistic alienation on an auditory level.

Furthermore, in polyglot films such as Nuovomondo, "languages have a marked diegetic function and are more than just a vehicle of content" (Ortega 2011, 22). The language used by Fortunata, her 
use of dialect and her refusal of other languages are indeed one of the most relevant linguistic aspects of the film. Proud of her cultural identity, she stands before the officers, unwilling to please them or to try and convince them to accept her. For similar reasons, she rejects the foreignness represented by Lucy, who is the first unfamiliar element that the old lady encounters before reaching the US, her first encounter with linguistic, cultural, gender and class "otherness".

Notwithstanding her familiarity with other worlds, since in Sicily she was a "medica", a healer of the rural community, she is not interested in what she deliberately refers to as "l'altro mondo" ("the other world"), instead of "il nuovo mondo" ("the New World"), as everybody else calls it. She refuses to understand its rules, priorities, habits and customs, and thus will not be granted permission to enter it. Together with her nephew, the other weak character in the film, insofar as he is mute, she is labeled as unfit to become American. It is possible to read this in terms of untranslatability, since both Fortunata and the boy reject translation. The old woman refuses to follow the rules imposed by the hosting system which will translate her into the new society, and eventually confines herself to silence; the boy cannot be translated as his voice remains unheard until the very end of the film, when he pronounces his first and only words, announcing his grandmother's desire to be sent back home.

In Kristeva's terms, like silent polyglots cementing their identity on their mastery of the mother tongue or, in contrast, complete silence and on the negotiation between them, these two powerful characters claim their right to stay at home, whether it be a physical location (Sicily/the mother land) or a linguistic location (dialect/the mother tongue, or silence) (Kristeva 1991). Among the mass of aliens striving to be recognized as humans, namely migrants striving to be accepted as citizens, Fortunata and the boy acknowledge the power of language and silence, resist translation and subsequent assimilation and embrace alienation. However, at the end of the film, when the officers manifest their will to repatriate both Fortunata and the boy, the woman stays silent and the boy suddenly starts to speak, explaining his grandmother's will 
to go back to Sicily and thereby affording the right for himself to be accepted into the New World.

\section{4. (Im)Possible Translation}

The film raises several questions that require multi-disciplinary interpretation. One of the most complex issues concerns the possibility of translating the culturally bound material in the story to a foreign audience, especially when this translation concerns language in the strict sense. While, on the one hand, it is necessary to make the film accessible to different audiences, on the other, "the central tenet of polyglot cinema is the representation of language diversity as its protagonists experience it" (Ortega 2011, 22). As De Meo states, the task of the translator of a film in which dialect plays such an important linguistic and socio-cultural part is difficult:

Dialect and culture-bound terms are closely related to the community they represent and therefore changeable and unstable in meaning as linked to the oral tradition, while subtitling should use the opposite strategy favoring stability, clarity and readability and denotative rather than connotative meaning. (2010, 25)

On several occasions, the translator had to omit interjections, explain metaphors and condense meaning for the sake of clarity, penalizing the rhythm of the dialogues. The fact that dialects are characterized by non-standard grammar, specific lexical features and a distinctive accent, as Díaz Cintas and Remael (2007) point out, makes the translator's task extremely difficult. These peculiarities of dialect further complicate the general technical constraints that translators/subtitlers have to take into consideration concerning, for instance, line breaks and the numbers of characters allowed. 
Thus, in the case of Nuovomondo, we are confronted with interesting choices and we shall focus on three different examples: 1) the translator opts for a functional solution that recreates the meaning of a Sicilian socio-cultural phenomenon; 2) the translator does not manage to convey the comic effect of a dialogue between Salvatore and an officer at the harbor, although meaning is not distorted; 3) the translator's choice does not reflect the true meaning of Fortunata's words.

\section{(Example 1)}

Fortunata: Eh allora, che volete?/ (sub) What do you want?

Rosa: Amuninne, amunnine./ (sub) Go on, go on.

A' parlare io?/ (sub) Shall I tell her?

Ce piglio' u scantu./ (sub) She's possessed.

At the beginning of the film, two female characters ask Fortunata for her healing help and they introduce the word "scantu", which is the Sicilian word for "fear". But the expression "ce piglio" $u$ scantu" (literally "he got quite a fright") refers to a more complex socio-cultural phenomenon, relating to a specific psychological and physical condition that the woman experiences before her departure for the US: she is afraid of leaving her home for good and marrying a man she does not know, and she expresses this through psychosomatic pain in her belly. The translator, in this case, manages to recreate the original meaning using the expression "she's possessed", which draws on a metaphysical component as implied by the Sicilian "ce piglio' u scantu."

(Example 2)

Officer: Ai sordomuti li rimpatriano./ (sub) They repatriate the deaf mutes.

Salvatore: Che ce fannu?/ (sub) What do they do? 
Officer: Li rimandano in patria./ (sub) They send them home. Salvatore: E unn'è?/ (sub) Where?

When the Mancuso family is at the harbor, and they are told that mute people are sent back home from the US, Salvatore does not understand the word "rimpatriare" ("repatriate") and asks the interlocutor where "patria" ("homeland") is. The English word "home" ("casa"), chosen by the translator to translate "patria" ("homeland") in the second affirmation of the officer, smoothes over this slight but important difference. The comic effect of Salvatore's question ("E unn'è?") is lost because it was constructed on the fact that the man did not know the meaning of the Italian word "patria". Again in keeping with technical restrictions, even if the translator had opted for the word "homeland" instead of "home", the comic effect would have been partially lost.

\section{(Example 3)}

Fortunata: Che volete e' noialtri?

Interpreter: What do we want from them?

Officer 2: Them who?

Interpreter: Noialtri chi signora?/ (sub) Who do you mean? Fortunata: Tutti i cristiani c'arrivammu du vecchiu munno. Interpreter: All the folk who came over from the old world. Officer 2: Would you explain to her that we want to know if they are fit enough to enter the new world?

Interpreter: Signora dobbiamo sapere se siete buoni per entrare nel nuovo mondo./ (sub) Madam we want to know if you are fit enough to enter the new world.

Fortunata: E vossia site nomine Dio?/ (sub) And you think you are God?/U decidite vossìa se semo buoni se nun semo buoni per trasire na vostra terra dell'altro munno?/ (sub) Who are you to decide if we are fit or not to enter this new world of yours? 
Here the translator opted for "New World" even when Fortunata uses the expression "l'altro munno", thus this crucial nuance gets lost in translation. Indeed, once her reference to "l'Altro Mondo" is omitted, the political act of Fortunata's to re-naming the US is not perceived by the foreign audience. In fact, her expression words in Sicilian may refer to the world all migrants come from as well as to another transcendental reality, and they thus embody a rejection of the idea that America represents the new. Nonetheless, the translator recreates the woman's sense of detachment from the US by choosing the expression "this new world of yours" to translate "na vostra terra dell'altro munno" instead of the simpler "to enter your new world." This example also highlights the role of the polyglot interpreter, who translates from Sicilian dialect into English for the officer, and then from English into Italian for Fortunata, who speaks dialect but also understands Italian.

These three examples show some of the difficulties translators and subtitlers can encounter when facing a polyglot text, especially when dialect is involved. Sometimes functional solutions are found, like in Example 1, whereas in certain cases part of the meaning or effect gets lost in translation, like in Example 2. While cultural knowledge of the source text is necessary and sufficient to recreate meaning as in the first case, the second example shows how wordplay in different languages does not always make it possible to obtain the same effect, be it acoustic or not. The third example is crucial for an understanding of the potential of translation to contaminate meaning, to interfere with the actual aim of the source language. The question here is whether Fortunata comes across as such a revolutionary character to the English audience if they have no access to a complete understanding of her controversial speech act.

\section{The politics of promotion and distribution}

Media and migration, according to cultural anthropologist Appadurai (1996) and echoed by numerous scholars in various 
disciplines, are two of the most important forces at work in shaping our transnational landscape as well as people's imagination. Hollywood cinema, in particular, has played a role in the representation of both dominant and dominated cultures to the general public over time, and migrants have been "translated" to fit in with pre-determined narratives, stereotypes and policies.

A significant element of investigation here is the way Nuovomondo, a successful European production, was presented to various audiences worldwide. This kind of analysis highlights the need to take into consideration the fact that cinema is a business and that films are not only artworks but also products to be sold. Indeed, there is a major difference, for instance, between the poster chosen for the Italian public, that chosen for the foreign one and that for the DVD.

The Italian poster shows Lucy in the foreground and the three men in the background, all immersed in milk. There is no reference to the journey or migration, and white is the main color of the image, focusing on Lucy's gaze towards an undefined point in front of her. Instead, the poster chosen for the foreign market (the French market is a case in point) shows a ship at sea. There is reference to the journey and to migration, as the people on board look like migrants, and Lucy is in the foreground on the deck. The DVD cover offers a third perspective, as it shows the Statue of Liberty, an icon that is not shown in the film, with Salvatore and Lucy gazing in opposite directions. The three images each allude to something different, stressing or ignoring the importance of the story of migration towards the American dream.

Trailers for the film also present the product to the public in different ways. The Italian and French trailers have no voiceover, and use excerpts from the original soundtrack. The only words in the Italian trailer are spoken by Salvatore, and come from the beginning of the film, when he asks the statue of Christ in the middle of the deserted Sicilian landscape whether he should leave or not. The rest of the narrative is evoked only by the images and 
sounds of the original soundtrack. The French version also includes other excerpts from the original soundtrack that feature actual film dialogues. The trailer for the foreign market, on the other hand, is completely occupied by a voiceover that narrates the whole story of migration and stresses the exceptionality of Salvatore's adventure from poor Sicily to the New World:

\begin{abstract}
Salvatore Mancuso was a simple man who lived a hard life, but one day he had a remarkable vision of a bountiful land. Now, like so many others, he will leave the old country behind and embark on an incredible journey. He will meet a mysterious woman and they will both discover that each has a dream of a better life. Together they will share an adventure that will bring them to the New World and change their life forever. (Golden Door, HD Trailer)
\end{abstract}

The translation of the film title Nuovomondo ("New World") into Golden Door also offers scope for reflection on the importance of the public's reception to this product. The door alludes to entering a specific place, and golden makes it sound appealing; the expression "Nuovo Mondo" in Italian is a clear reference to America, which is obviously not clear to the American public. The foreign audience's imagination is not activated when reading or hearing these two words as much as it is for Italians. Beside the desire to challenge stereotypes, this is probably the reason underlying the decision to avoid any iconic reference to America in the Italian poster, since the word "Nuovomondo" is already a direct reference to it. Finally, the expression "Golden Door" is clearly related to the idea of the Eldorado that all immigrants expected to find on arrival in the New World, and it is probably exactly what the foreign audience expects to see on the screen. But ultimately, America is not there, or rather it is shrouded in thick fog. 


\section{Conclusions}

Nuovomondo offers the opportunity to investigate the image of America from the migrant's point of view, from a European point of view, and to question its master narrative of modernity. Cinema is one of the most powerful forms of narrating nation-building since the camera reflects and, at the same time, creates reality. As Marubbio notes:

Films are social narratives and politically inspired works of art that inform us about our society's fears, desires, politics, conflicts, and structures of power. Most importantly, I consider the artistry and visual machinations of films in relation to the political message presented to the viewer. How one reads, remembers, and reacts to a film depends on how it is constructed as a visual product and how it is promoted (...) Film, as a voyeuristic medium, offers a lens through which to analyze the psychological and sociological structures created through representations of subservient, simplistic, self-destructive Others. (2006, ix)

The master narrative of the migration of Italians towards America, their struggle to be translated and to translate themselves into the new regime of rules, habits, cultural and linguistic attitudes is a fruitful field of research for those who are interested in the role language and translation play practically and metaphorically on the border between different worlds. Especially when we are confronted with the image of a powerful system which tries to annihilate a weaker other through acts of translation, exercising what Kral, recalling Bourdieu, calls "la violence symbolique de la langue du colon" (the symbolic violence of the colonizer's language) $(2011,131)$. In a certain sense, the multiple languages of the film resist total translation into English, and at the same time, the characters position themselves in a third linguistic space between Italian and the master language of power. 
The negotiation between language, silence and translation that is constantly required in the "translation-scape" (Taronna 2009) we still live in, after centuries of mass migration worldwide, may be symbolized by the character of Fortunata in Nuovomondo. She could be defined as the most "aware" figure, the agent, the one who perceives the subtle power relations inherent in the process of translation and who resists them. Her ultimate act of silence and her refusal to accept assimilation shed light on the forms of inclusion, subversion or legitimation articulated in the American system. The US is indeed seen in the film through the lens of its un-ethical response to otherness, and attention is thus driven along the guiding master narratives of homeland, citizenship, identity, gender, language and migration (Polezzi 2012).

\section{References}

Appadurai, Arjun. Modernity at Large: Cultural Dimensions of Globalization. Minneapolis and London: University of Minnesota Press, 1996.

Berger, Verena; Komori, Miya. (eds.) Polyglot Cinema: Migration and Transcultural Narration in France, Italy, Portugal and Spain. Wien: Lit Verlag, 2010.

Bhabha, Homi. The Location of Culture. London and New York: Routledge, 1994.

Cronin, Michael. Translation Goes to the Movies. London and New York: Routledge, 2009.

. Across the Lines. Travel, Language, Translation. Cork: Cork University Press, 2000. 
. Translation and Identity. London: Routledge, 2006.

De Meo, Mariagrazia. Subtitling Dialect and Culture-bound Language. Roma: Carocci, 2010.

Díaz Cintaz, Jorge; Remael, Aline. Audiovisual Translation: Subtitling. London and New York: Routledge, 2007.

Kral, Françoise. "Du silence du polyglotte au bégaiement de la langue: vacillations et errances de la voix diasporique." Questions de Voix, Tropismes 17 (2011). Available at <http://ojs.u-paris10.fr/index.php/tropismes/article/ view/120/195>.

Kristeva, Julia. Strangers to Ourselves. New York: Columbia University Press, 1991.

Mamula, Tijana. Cinema and Language Loss. Displacement, Visuality and the Filmic Image. London and New York: Routledge, 2013.

Marubbio, M. Elise. Killing the Indian Maiden: Images of Native American Women in Film. Lexington: University Press of Kentucky, 2006.

Moretti, Enrico. "Social Networks and Migrations: Italy 1876-1913." The International Migration Review 33.3 (1999): 640-657.

Ortega, Elena S. "Subtitling and the Relevance of Non-verbal Information in Polyglot Films." New Voices in Translation Studies 7 (2011): 19-34.

Pethö, Agnes. Cinema and Intermediality: The Passion for the In-Between. Newcastle upon Tyne: Cambridge Scholars Publishing, 2011.

Polezzi, Loredana. "Translation and Migration." Translation Studies 5 (2012): 345-356.

Roediger, David. Working Towards Whiteness. How America's Immigrants Became White. New York: Basic Books, 2005. 
Taronna, Annarita. Translationscapes. Comunità, lingue e traduzioni interculturali. Bari: Progedit, 2009.

Wagner, Peter. (ed.) Icons, Texts, Iconotexts. Essays on Ekphrasis and Intermediality. Berlin: De Gruyter, 1996.

Zaccaria, Paola. "Ripresa (cine)fotografica e/o come traduzione: il caso Nuovo Mondo." Il testo oltre i confini. Paesaggi, scambi, migrazioni. Capano Perrone, Lucia (ed.). Bari: Palomar (2009): 173-203.

Recebido em: 17/06/2016 Aceito em: 23/09/2016 Publicado em janeiro de 2017 